\title{
Kondisi fisik kerabang telur ayam ras petelur cokelat di Pasar Pinasungkulan Manado
}

\author{
Nison Wakur, E.S. Tangkere*, L.J. Lambey, Y.H.S. Kowel \\ Fakultas Peternakan Universitas Sam Ratulangi Manado 95115 \\ *Korespondensi (corresponding author): evacuree.s@gmail.com
}

\begin{abstract}
ABSTRAK
Suatu penelitian telah dilakukan untuk mengetahui kondisi fisik kerabang telur-telur segar ayam ras petelur cokelat di pasar Pinasungkulan Manado. Variabel yang diamati adalah berat telur pada tiga categori ukuran umum (kecil, sedang dan besar) dan kondisi kerabang (kebersihan, kehalusan/tekstur dan warna). Rata-rata berat telur dari tiga kategori ukuran yang dibuat para pedagang adalah telur ukuran kecil 51,57 gram, telur ukuran sedang 62.03 gram, dan telur ukuran besar 70.68 gram. Nilai kondisi kerabang telur-telur ayam ras petelur cokelat untuk kebersihannya dari agak bersih sampai bersih $(3,58-3,82)$; teksturnya dari agak halus sampai halus $(3,64-3,85)$; dan warnanya dari agak pudar sampai cokelat $(2,79-$ $3,85)$. T-test paired menunjukkan bahwa kondisi kerabang ayam ras petelur cokelat ukuran telur kecil lebih baik dari kondisi kerabang telur ukuran sedang dan telur ukuran besar, dilihat dari kebersihan, tekstur dan warna kerabang, juga didapati bahwa pedagang telur di pasar Pinasungkulan Manado membuat kategori ukuran atau berat telur belum secara baik dan terstandar.
\end{abstract}

Kata kunci: telur cokelat, kerabang, kebersihan, kehalusan/tekstur, warna.

\begin{abstract}
THE EGGSHELLS' PHYSICAL CONDITION OF BROWN CHICKEN EGGS AT PINASUNGKULAN MARKET MANADO. A study was conducted to examine the eggshells' physical condition of fresh-brown chicken eggs (table eggs) at the Pinasungkulan market, in Manado city. The variables taken were egg weight in three general size categories (small, medium and large) and eggshells condition (cleanliness, smoothness/ texture and color). The averages egg weight of the fresh-brown chicken eggs in three size categories made by egg sellers were 51.57 grams for small size eggs, 62.03 grams for medium size eggs and 70.68 grams for large size eggs, respectively. The eggshells' condition values of freshbrown eggs were from slightly clean to clean $(3.58$ - 3.82) on cleanliness; from slightly smooth to smooth (3.64 - 3.85) on texture; and from slightly faded to brown (2.79 - 3.85) on color. T-test paired was showed that the eggshells' physical condition of small size eggs was better than that of medium size and large size eggs seen from their eggshells' cleanliness, smoothness/ texture and their color, It found also that the egg seller in Pinasungkulan Market, Manado had not been carefully made and well standardized the egg size or egg weight categories.
\end{abstract}

Keywords: brown eggs, eggshell, cleanliness, smoothness/texture, color. 


\section{PENDAHULUAN}

Telur merupakan salah satu produk peternakan yang memberikan sumbangan terbesar bagi tercapainya kecukupan gizi manusia. Dari sebutir telur, manusia mendapatkan hampir semua zat-zat nutrisi yang cukup berimbang komposisinya serta mudah dicerna, seperti kualitas protein dan asam-asam amino yang tinggi, lemak dan vitamin serta mineral (Argo et al., 2013). Telur dianjurkan diberikan kepada anakanak, dan orang sakit untuk proses pertumbuhan dan perkembangan, serta untuk mempercepat penyembuhan, juga untuk menjaga kesehatan tubuh (Cook dan Briggs, 1977; Mine dan Kovacs-Nolan, 2004).

Beberapa konsumen atau pelanggan yang sering berbelanja telur ayam ras segar di pasar tradisional mengatakan bahwa, meskipun harga telur ayam ras cokelat naik tinggi, terutama menjelang hari-hari raya besar, namun harga telur masih dapat dijangkau, tapi terkadang mereka kecewa mendapati ada telur-telur ayam segar yang mereka beli, ternyata sudah mengalami penurunan mutu, dimana keadaan putih dan kuning telur sudah cair atau encer; bahkan terkadang tidak dapat dikonsumsi, padahal telur-telur yang mereka beli kerabangnya utuh atau tidak retak, bahkan para pedagang dimana mereka membeli telur mengatakan bahwa telur-telur yang mereka jual baru berumur sehari atau beberapa hari (kurang dari satu minggu). Menurut Winarno dan Kaswara (2002), telur-telur yang kerabangnnya menempel feses atau noda kotoran, selama masa penyimpanan akan berdampak pada kualitas internal telur. Bakteri akan dengan mudah masuk melalui pori-pori yang semakin terbuka seiring dengan umur penyimpanan. Penetrasi bakteri pathogen pada telur yang umum adalah bakteri Salmonella sp (Afifah, 2013; Messens et al., 2005; Wahyuningsih, 2019)

Salah satu pasar yang cukup besar dan ramai dikunjungi masyarakat kota
Manado adalah pasar Pinasungkulan yang berada di kelurahan Ranotana Weru, kecamatan Wanea. Berdasarkan presurvey, di pasar Pinasungkulan ada 20 (dua puluh) tempat penjualan telur atau pedagang telur dan dari duapuluh pedagang telur, hanya ada 2 (dua) orang yang menjadi penjual telur utama, atau dengan kata lain tidak ada produk makanan lainnya yang mereka jual, tetapi hanya telur, sedangkan 18 (delapan belas) pedagang lainnya, mereka menjual telur dan juga menjual beberapa produk bahan makanan, atau peralatan masak / peralatan makan lainnya. Berdasarkan pengamatan, walaupun telur-telur yang dijual oleh ke 18 pedagang tersebut, bukanlah produk jualan utama, tetapi telur-telur yang mereka jual selalu berada di deretan paling depan, dengan kategori harga masing-masing kelompok telur ataupun dengan kategori ukuran telur yang mereka buat, tetapi secara umum kategori yang mereka buat adalah ukuran telur kecil, sedang dan ukuran telur besar.

Menurut para pedagang telur, khususnya pedagang telur utama yang sudah berdagang hampir 30 (tiga puluh) tahun, bahwa dulunya telur-telur yang dijual di pasar Pinasungkulan Manado dibawa oleh pedagang-pedagang pengumpul telur dari beberapa sumber atau daerah penghasil telur, dan nanti setelah jumlah telur sudah terkumpul cukup banyak, maka para pedagang pengumpul tersebut membawa telur-telur tersebut ke pasar atau dijual ke pedagang pasar. Sekarang atau kurun waktu 10 (sepuluh) tahun belakangan ini, keadaannya jauh berbeda, karena para produsen atau para peternak ayam ras petelur, datang langsung ke pasar membawa hasil panen mereka, bahkan sering para peternak menelpon para pedagang telur di pasar, jika mereka butuh pasokan telur, maka peternak akan segera membawa telur-telur mereka ke para pedagang yang membutuhkan. 
Secara umum tempat berjualan di pasar Pinasungkulan Manado sekarang ini, juga sudah cukup jauh berbeda dibanding dengan keadaan pasar kira-kira 10 (sepuluh) tahun yang lalu ataupun berpuluh-puluh tahun yang lalu, dimana menurut para pedagang, dahulu mereka harus mendirikan tenda atau lapak masingmasing, dimana tidak jarang saat hari panas jualan mereka dapat terpapar sinar matahari langsung dan pada saat hari hujan, barang atau bahan dagangan mereka terkena percikan air hujan bahkan kadang terguyur air hujan. Sekarang tempat berjualan yang didirikan pemerintah dapat dikatakan sudah lebih baik, setidaknya sudah terlindung dari sinar matahari langsung ataupun jika hujan tidak lagi kena percikan atau guyuran air hujan.

Jika keadaan tempat berjualan para pedagang di pasar Pinasungkulan Manado sudah lebih baik dan rantai distribusi telur juga sudah lebih pendek atau lebih cepat, dan telur yang dibeli konsumen dalam keadaan utuh (tidak pecah) tapi mengapa konsumen masih menjumpai telur-telur segar dengan kualitas yang tidak baik? Suatu bahan makanan, baik itu yang berasal dari hewan ataupun tumbuhan sudah dianggap rusak jika terjadi penyimpangan-penyimpangan yang melewati batas, sehingga bahan makanan tersebut tidak dapat diterima oleh panca indera atau parameter lain yang bisa digunakan (Ray dan Bhunia, 2013).

Sebagaimana diketahui, selain harga dan ukuran telur atau berat telur, faktor lainnya yang mempengaruhi selera konsumen dalam memilih telur adalah kondisi fisik telur dalam hal ini kerabang telur. Penampilan fisik telur yang pertama kali akan dilihat adalah kondisi kerabang. Untuk itu suatu penelitian telah dilakukan untuk mengetahui kondisi fisik kerabang telur segar ayam ras petelur cokelat yang dijual di pasar Pinasungkulan Manado.

\section{MATERI DAN METODE PENELITIAN}

Penelitian telah dilaksanakan di pasar Pinasungkulan, kelurahan Ranotana Weru, kecamatan Wanea, kota Manado dan dilanjutkan di Laboratorium Teknologi Hasil Ternak Fakultas Peternakan, Universitas Sam Ratulangi Manado.

Materi yang digunakan dalam penelitian ini adalah para pedagang telur di pasar Pinasungkulan, dan telur-telur segar ayam ras petelur cokelat yang terdiri dari telur-telur segar kategori kecil 72 butir, telur-telur segar kategori sedang 72 butir dan telur-telur segar kategori besar 72 butir atau total telur segar yang digunakan selama penelitian sebanyak 216 butir.

Dalam Penelitian digunakan peralatan seperti daftar pertanyaan (list of Questioner), wadah atau baki telur, timbangan analitik, kamera handphone, foto warna telur, daftar isian data, alat tulis menulis lainnya

Penelitian dilaksanakan dengan metode survey dan purposive sampling atau purposive-random sampling. Beberapa konsumen yang membeli telur utuh, dan pedagang telur yang ada di pasar Pinasungkulan Manado, dijadikan responden (purposive sampling) diwawancarai dengan sederet pertanyaan (list of Questioner). Selanjutnya sampel telur-telur segar diambil atau dibeli dari pedagang telur yang memiliki volume dan jumlah penjualan telur terbesar dalam sehari, dan akhirnya ditetapkan 4 (empat) orang pedagang telur yang terdiri dari 2 (dua) orang pedagang telur utama yang hanya berjualan telur saja dan 2 (dua) orang pedagang lainnya yang berjualan telur dengan bahan pangan dan peralatan dapur lainnya (purposive sampling). Untuk telur pengambilannya diambil secara acak (random) pada kategori ukuran kecil (small), sedang (medium) dan ukuran besar (large). Pengambilan dan pengamatan sampel telur-telur segar 
dilakukan sebanyak tiga kali pada kesempatan waktu yang berbeda atau sebanyak 24 butir setiap pembelian dan pengamatan. Sampel telur walaupun pengambilannya secara acak, tapi pembeliannya pada pedagang yang sama dengan kategori telur yang sama.

Penilaian dilakukan dengan cara meranking kondisi telur, dimana jika mendekati angka 5 (lima) maka kondisi kerabang semakin baik, dalam artian kondisi kerabang sangat bersih, sangat halus teksturnya dan sangat cokelat warnanya. Sebaliknya, jika mendekati angka 1 (satu), maka kondisi kerabang semakin kurang baik, dalam artian kondisi kerabang sangat kotor, sangat kasar teksturnya dan sangat pudar warnanya.

Data yang diperoleh ditabulasi untuk melihat nilai rata-rata dan standar deviasi, pada semua variable pengamatan, namun untuk variable berat telur yang menggambarkan kategori ukuran telur tidak dilakukan T-Test paired, sedangkan untuk variable kebersihan, tekstur dan warna telur dilanjutkan dengan T-Test paired. Uji berpasangan atau T-Test paired pada variabel kebersihan kerabang telur antara kategori telur kecil dan telur sedang atau antara kategori telur kecil dan telur besar dan seterusnya dilakukan juga pada variable lainnya, dengan tujuan untuk melihat apakah ada perbedaan yang signifikan terhadap kondisi fisik kerabang antara kategori telur-telur segar di pasar Pinasungkulan Manado.

Variabel yang diamati adalah:

a. Berat telur (gram)

Telur-telur yang dibeli berdasarkan kategori ukuran telur dari para pedagang, satu persatu ditimbang beratnya, lalu dihitung berat rata-rata (gram) per butirnya dan dilihat range berat telur per kategori ukuran telur. Data dianalisis secara deskriptif.

b. Kebersihan kerabang telur

Telur-telur yang telah ditimbang berdasarkan kategori ukuran telur kemudian diamati kebersihan kerabangnya satu demi satu, apakah ada feses yang menempempel, atau noda feses dan noda darah, juga bercak seperti jamuran, atau jatuhan pakan dan lain-lain, lalu dibandingkan ke telur yang telah diurutkan dari yang paling kotor sampai yang paling bersih. Tingkat kebersihan telur dibuat ranking ( $5=$ sangat bersih, $4=$ bersih, $3=$ agak bersih/kotor, $2=$ kotor, $1=$ sangat kotor). Setelah data ditabulasi dilanjutkan $T$ Test paired.

c. Tekstur kerabang telur

Telur-telur yang telah diamati kebersihan kerabangnya, kemudian dibersihkan dengan tissue basah (sekaligus melihat lagi kebersihan kerabangnya), lalu diamati tekstur/ kehalusan kerabangnya dengan meraba permukaan kerabang telur, apakah mulus, kasar, bergelombang ataukah ada tonjolan-tonjolan seperti butiran pasir atau tonjolan sebesar jerawat. Tingkat kehalusan atau kemulusan kerabang telur juga dibuat ranking (5= sangat halus, $4=$ halus, $3=$ agak halus/kasar, 2= kasar, 1= sangat kasar). Setelah data ditabulasi, dilanjutkan $T$ Test paired.

d. Warna kerabang telur

Telur-telur juga diamati warna kerabangnya. Kadar warna kerabang dibuat sendiri berdasarkan warna telur yang ditemukan saat membeli telur, dimana telur-telur dengan intensitas warna yang berbeda tersebut diurutkan dari yang paling cokelat sampai yang paling pudar, lalu di foto untuk kemudian dijadikan patokan dalam menilai warna telur-telur yang lain. Tingkat atau kadar warna cokelat kerabang telur juga dibuat ranking $(5=$ sangat cokelat, $4=$ coklat, $3=$ agak coklat/pudar, $2=$ pudar, $1=$ sangat pudar). Setelah data ditabulasi dilanjutkan T-Test paired. 


\section{HASIL DAN PEMBAHASAN}

Rata-rata berat telur dan kondisi kerabang telur ayam ras petelur cokelat di pasar Pinasungkulan, kelurahan Ranotana Weru, kecamatan Wanea, Manado dapat dilihat pada Tabel 1 .

\section{Berat telur ayam ras petelur cokelat}

Sebagaimana dapat dilihat pada Tabel 1, rata-rata berat telur dari tiga kategori ukuran yang dibuat para pedagang pasar Pinasungkulan Manado adalah untuk kategori telur kecil (small) beratnya ratarata 51,57 gram, kategori telur sedang (medium) beratnya rata-rata 62,03 gram, dan kategori telur besar (large) beratnya rata-rata 70,68 gram. Para pemasok telur pada dasarnya sudah mengklasifikasikan telur-telur yang mereka jual ke pedagang pasar, namun para pedagang pasar biasanya kembali membuat klasifikasi ukuran telur berdasarkan kemauan mereka. Penentuan klasifikasi standar berat telur per butir di negara Amerika, Australia, Jepang dan negara-negara maju lainnya telah dilakukan secara seksama begitupun dengan harga jual (Kekeocha, 1984; Sudaryani, 2000). Di kota Manado, terutama di pasar-pasar tradisional dan kios atau warung, penjualan telur tidak memiliki klasifikasi yang standar atau baku. Seperti pernyataan Sudaryani (2000), dimana kalau di pulau Jawa, konsumen lebih menyukai telur dengan jumlah butiran yang lebih banyak dalam setiap kilogramnya, berbeda dengan konsumen di daerah-daerah lainnya di luar pulau Jawa. Konsumen telur di kota Manado dan sekitarnya, yang berbelanja di pasar tradisional atau pasar rakyat, umumnya membeli telur dengan cara memilih satu per satu telur berdasarkan ukurannya dan harganya yang ditentukan para pedagang, seperti halnya di pasar Pinasungkulan Manado.

Pada penelitian kali ini, rata-rata ukuran telur per kategori yang dibuat para pedagang pasar Pinasungkulan Manado, masuk dalam kisaran ukuran atau berat telur per kategori (kecil, sedang, besar) yang berlaku di negara Jepang dimana kategori telur ukuran kecil < 53 gram, sedang 53-63 gram dan besar 63-73 gram (Sumarni dan Djuarnani, 1995), tapi berbeda dari kategori ukuran dan berat telur yang berlaku di negara Amerika Serikat dimana untuk kategori telur ukuran kecil 42-49 gram, sedang 49-56 gram dan besar 56-65 gram (Heryandi, Y; 2006). Namun, tidak berarti bahwa para pedagang telur di pasar Pinasungkulan Manado mengikuti standar kategori ukuran atau berat telur dari negara Jepang, karena kisaran telur pada penelitian kali ini, untuk kategori telur kecil 46,07-58,60 gram, kategori telur sedang 57,15-68,99 gram dan kategori telur besar 65,91-79,28 gram, berbeda dari kategori kisaran berat telur yang berlaku di Jepang.

Tabel 1. Rerata Berat Telur, Kebersihan Kerabang Telur, Tekstur Kerabang Telur dan Warna Kerabang Telur Ayam Ras Petelur Cokelat di Pasar Pinasungkulan, Manado

\begin{tabular}{lllll}
\hline \multirow{2}{*}{ Kategori Telur } & \multirow{2}{*}{ Berat $($ gram $)$} & \multicolumn{3}{c}{ Kondisi kerabang } \\
\cline { 3 - 5 } & & Kebersihan & Tekstur & Warna \\
\hline KECIL & $51,57 \pm 3,05$ & $3,82 \pm 0,48^{\mathrm{a}}$ & $3,85 \pm 0,69^{\mathrm{a}}$ & $3,85 \pm 0,60^{\mathrm{a}}$ \\
SEDANG & $62,03 \pm 3,14$ & $3,67 \pm 0,53^{\mathrm{b}}$ & $3,67 \pm 0,77^{\mathrm{ab}}$ & $3,31 \pm 0,49^{\mathrm{b}}$ \\
BESAR & $70,68 \pm 2,26$ & $3,58 \pm 0,50^{\mathrm{bc}}$ & $3,64 \pm 0,66^{\mathrm{b}}$ & $2,79 \pm 0,50^{\mathrm{c}}$ \\
\hline
\end{tabular}

Ket: Parameter berat telur tidak dilakukan uji perbedaan nilai rerata antar kategori. Superskrip $\left({ }^{\text {abc }}\right)$ berbeda pada kolom yang sama menunjukan perbedaan $(\mathrm{P}<0,05)$. 


\section{Kondisi fisik kerabang telur ayam ras petelur cokelat}

Sebagaimana dapat dilihat pada Tabel 1, kondisi fisik kerabang dari sampel telur-telur ayam ras petelur cokelat di pasar Pinasungkulan untuk telur-telur berukuran kecil memiliki kerabang bersih (nilai 3,82), kemudian telur-telur berukuran sedang memiliki kerabang agak bersih (nilai 3,67), dan telur-telur berukuran besar memiliki kerabang agak bersih (nilai 3,58)

Berdasarkan T-Test paired, kebersihan kerabang telur antara kategori telur didapati bahwa telur-telur berukuran kecil kebersihan kerabangnya berbeda nyata $(\mathrm{P}<0,05)$ dibandingkan dengan kebersihan kerabang telur-telur berukuran sedang dan telur-telur berukuran kecil tersebut kebersihan kerabangnya berbeda sangat nyata $(\mathrm{P}<0,01)$ dibandingkan dengan kebersihan kerabang telur-telur berukuran besar. Akan tetapi, telur-telur berukuran sedang kebersihan kerabangnya tidak berbeda nyata dengan kebersihan telur-telur berukuran besar. Dengan kata lain, telur-telur segar ayam ras petelur cokelat yang dijual di pasar Pinasungkulan Manado, untuk telur-telur berukuran kecil, kondisi kerabangnya lebih bersih dari telur-telur berukuran sedang, bahkan kebersihan kerabang telur-telur berukuran kecil jauh lebih bersih daripada telur-telur berukuran besar. Sedangkan kondisi kebersihan kerabang telur-telur berukuran sedang, tidak berbeda dari telur-telur berukuran besar.

Kebersihan kerabang telur-telur segar ayam ras petelur cokelat ukuran kecil lebih bersih dari kerabang telur-telur berukuran sedang dan besar, mungkin dikarenakan telur-telur berukuran kecil didapat dari induk yang baru bertelur dan kondisi kandang masih dalam keadaan baik dan lebih bersih dari keadaan kandang ayam-ayam petelur yang umur atau masa bertelurnya sudah lebih lama dan menghasilkan telur-telur berukuran sedang ataupun ukuran besar. Biasanya semakin lama kandang digunakan, kondisi kandang menjadi kotor. Pada penelitian kali ini didapati bahwa telur-telur ukuran sedang dan ukuran besar umumnya permukaan kerabang terdapat sedikit kotoran menempel dan noda kotoran. Hal ini mungkin dikarenakan luas penampang permukaan kerabang telur-telur ukuran sedang dan besar lebih luas dari permukaan penampang kerabang telurtelur ukuran kecil, sehingga kemungkinan jatuhan feses atau bahan pakan mengenai kerabang telur-telur pada dua kategori ukuran tersebut lebih besar daripada permukaan penampang kerabang telurtelur berukuran kecil. Perlu kami informasikan bahwa telur-telur yang dijual di pasar Pinasungkulan didatangkan dari beberapa daerah sumber penghasil telur, sehingga dapat pula kami asumsikan bahwa telur-telur berukuran sedang dan besar mungkin berasal dari sumbersumber peternakan yang berbeda, dimana frekuensi pengumpulan telur tidak sering (mungkin hanya 1 kali sehari), dan selesai dipanen tidak ada tindakan membersihkan telur, sehingga pada kerabang telur masih terlihat feses ukuran kecil yang menempel atau noda feses yang membekas pada kerabang telur. Kontaminansi bakteri atau cemaran pada telur umumnya berasal dari lingkungan peternakan dan kondisi selama penyimpanan telur serta dapat juga terjadi di pasar-pasar (Chaemsanit et al., 2015).

Kalau melihat standar tingkatan mutu kerabang telur, maka dapat dikatakan kondisi kebersihan kerabang dari sampel telur-telur di pasar Pinasungkulan Manado berada pada tingkat mutu II (BSNI, 2008).

Sebagaimana dapat dilihat pada Table 1, kondisi fisik kerabang dari sampel telur-telur ayam ras petelur cokelat di pasar Pinasungkulan untuk telur-telur berukuran kecil memiliki tekstur kerabang halus (nilai 3,85), kemudian telur-telur berukuran sedang memiliki tekstur 
kerabang agak halus (nilai 3,67), dan telurtelur berukuran besar memiliki tekstur kerabang agak halus (nilai 3,64).

Berdasarkan T-Test paired, tekstur kerabang telur antara kategori telur didapati bahwa telur-telur yang berukuran kecil, tekstur kerabangnya tidak berbeda nyata dengan tekstur kerabang telur-telur berukuran sedang akan tetapi telur-telur berukuran kecil, tekstur kerabangnya berbeda nyata $(\mathrm{P}<0,05)$ dengan telur-telur berukuran besar. Selanjutnya, tekstur kerabang telur-telur berukuran sedang berbeda tidak nyata dibandingkan dengan tekstur kerabang telur-telur berukuran besar. Dengan kata lain, tekstur kerabang telur-telur segar ayam ras petelur cokelat yang dijual di pasar Pinasungkulan Manado, untuk telur-telur berukuran kecil kondisi teksturnya hampir sama dengan tekstur telur-telur berukuran sedang, tetapi telur-telur segar berukuran kecil kondisi teksturnya masih lebih halus daripada tekstur telur-telur berukuran besar. Selanjutnya kondisi tekstur kerabang telurtelur berukuran sedang tidak jauh berbeda dengan tekstur kerabang telur-telur berukuran besar.

Pada penelitian ini, semakin besar ukuran telur, kehalusan teksturnya semakin berkurang. Hal ini mungkin disebabkan seiring dengan bertambahnya ukuran telur, luas penampang permukaaan kerabang telur semakin luas, dan permukaan pori-poripun semakin melebar atau terbuka, sedangkan banyaknya kutikula yang dihasilkan hampir sama dari waktu ke waktu selama periode bertelur sehingga tidak dapat menutup permukaan kerabang secara penuh dan merata (Roberts dan Ball, 1998) dan mungkin disebabkan lapisan kutikula yang menipis karena umur telur, tempat serta temperature penyimpanan yang tidak memadai (Kusnadi, 2007). Penelitian yang dilakukan Samiullah et al. (2016) melaporkan bahwa lapisan kutikula yang menutup pori-pori kerabang telur dari ayam yang dipelihara pada sistim barn lebih tinggi dibandingkan lapisan kutikula yang menutup pori-pori telur dari ayam yang dipelihara pada sistim free range dan cages dan penyelesaian lapisan kutikula telur yang diambil dari flok ayam berumur 44 minggu menutupnya lebih sempurna daripada penyelesaian lapisan kutikula telur dari flok ayam berumur 64 dan 73 minggu (Wedana et al., 2017). Stewards dan Abbott (1972), menyatakan umumnya semakin besar telur, semakin tipis kerabang dan kerabang yang tipis relatif berpori lebih banyak dan berpori besar, sehingga dapat mempercepat turunnya kualitas telur akibat penguapan dan pembusukan isi telur.

Pada penelitian kali ini, telur-telur segar yang memiliki kelainan tekstur kerabang ada $2,78 \%$ (pimple) pada telur ukuran kecil, 5,56\% (pimple dan sandpaper) pada telur ukuran sedang dan $2,78 \%$ (sandpaper) pada telur ukuran besar. Walaupun pada bagian telur lainnya cukup halus, tapi tonjolan keras berupa pasir dan jerawat membuat telur pada akhirnya dikategorikan sangat kasar (nilai 1). Menurut Wiradimadja et al. (2006) bahwa kondisi ini dapat terjadi karena saluran reproduksi ayam petelur terganggu, dimana proses pembentukan telur berlangsung lebih lama, menyebabkan terjadinya tambahan butiran-butiran kalsium pada permukaan kerabang telur. Selanjutnya Winarno dan Kaswara (2002) melaporkan bahwa kerabang telur yang kasar juga ditemukan pada telur-telur ayam ras impor yakni bervariasi antara $10-18 \%$.

Kalau melihat standar tingkatan mutu kerabang telur, maka dapat dikatakan kondisi tekstur dari sampel telur-telur di pasar Pinasungkulan Manado berada pada tingkat mutu II (BSNI, 2008).

Sebagaimana dapat dilihat pada Tabel 1, kondisi fisik kerabang dari sampel telur-telur ayam ras petelur cokelat di pasar Pinasungkulan untuk telur-telur berukuran kecil memiliki warna kerabang cokelat (nilai 3,85), kemudian telur-telur 
berukuran sedang memiliki warna kerabang agak cokelat (nilai 3,31), dan telur-telur berukuran besar memiliki warna kerabang agak pudar (nilai 2,79)

Berdasarkan T-Test paired, warna kerabang telur antara kategori telur didapati bahwa telur-telur yang berukuran kecil, warna kerabangnya berbeda sangat nyata $(\mathrm{P}<0,01)$ dibandingkan dengan warna kerabang telur-telur yang berukuran sedang dan warna kerabang telur-telur yang berukuran besar. Bahkan, warna kerabang telur-telur berukuran sedang juga berbeda sangat nyata $(\mathrm{P}<0,01)$ dibandingkan dengan warna kerabang telur-telur berukuran besar. Jadi dapat dikatakan telur-telur segar ayam ras petelur cokelat yang dijual di pasar Pinasungkulan Manado, kondisi warna kerabang telur-telur berukuran kecil jauh lebih coklat daripada warna kerabang telur-telur berukuran sedang dan juga dari warna telur-telur berukuran besar. Selanjutnya warna kerabang telur-telur berukuran sedang masih lebih coklat dari warna kerabang telur-telur berukuran besar.

Pada penelitian kali ini, didapati trend warna kerabang yang umum pada telur ayam ras petelur coklat, dimana semakin besar ukuran telur warna kerabangnya semakin pudar atau semakin berat telur, semakin pudar warna coklatnya. Ukuran telur mempengaruhi warna kerabang adalah suatu hal yang wajar jika semakin bertambah umur ayam, semakin besar telur yang dihasilkan, semakin warnanya memudar. Hal ini mungkin disebabkan luas penampang permukaan kerabang telur yang semakin luas seiring dengan bertambahnya ukuran isi telur, sedangkan banyaknya atau jumlah pigmen yang diproduksi hampir sama dari waktu ke waktu selama periode bertelur (Mampioper et al., 2008). Memudarnya warna kerabang telur juga dapat disebabkann karena suhu lingkungan yang tinggi sehingga ayam menjadi stress (Setiawati et al., 2016) dan dapat diperparah dengan sistim pemeliharaan khususnya kandang yang tidak mendukung kenyamanan ayam. Tangkere et al. (2000) melaporkan bahwa warna kerabang telur-telur segar ayam ISA Brown yang dipelihara pada sistim sangkar (cages) terlihat lebih pudar atau terang dibandingkan warna kerabang telur-telur segar ayam ISA brown yang dipelihara dengan sistim barn pada kondisi temperature lingkungan tinggi (hot weather). Di lain pihak, Samiullah et al. (2016) melaporkan bahwa warna kerabang telur dari flok yang dipelihara dengan sistim cage lebih gelap dibandingkan warna kerabang telur dari flok ayam yang dipelihara pada sistim barn dan free range. Kasmiati et al. (2018) melaporkan bahwa warna telur ayam ras yang beredar di kota Monokwari, warna cokelatnya dan ukurannya bervariasi dari waktu ke waktu.

Menurut Yang et al. (2009) bahwa warna kerabang telur ayam cokelat yang semakin pudar mengakibatkan menurunnya kelenturan kerabang dan ketebalan kerabang. Selanjutnya Jazil et al. (2013) melaporkan bahwa penurunan atau penyusutan berat telur dan Haugh Unit telur semakin cepat tejadi pada telur ayam ras cokelat yang berwarna terang dibandingkan telur berwarna cokelat tua.

Pada penelitian kali ini, pada beberapa telur segar ukuran sedang, dan ukuran besar didapati pigmentasi kerabang penyebarannya tidak merata atau pigmen tidak menutup permukaan telur secara merata sehingga ada bagian telur yang warna cokelatnya semakin pudar dan bahkan dijumpai beberapa butir telur warna kerabangnya terlihat seperti bercak atau bintik-bintik pigmen gelap dan bercak atau bintik putih ekstra kalsium yang juga memberi kesan telur terlihat kotor. Menurut Hauser et al. (1952), telur yang kerabangnya berbintik-bintik termasuk kategori telur yang kurang baik. Kejadian pigmentasi yang tidak merata pada kerabang seperti bercak atau bintik-bintik pigmen mungkin disebabkan ayam 
mengalami stress. Solomon (1991) menyatakan bahwa, kondisi dari kerabang telur merupakan petunjuk yang dapat diandalkan untuk menilai apakah ayam merasa nyaman atau puas dengan lingkungan tempat tinggalnya. Batkowska et al. (2014) menyatakan bahwa perubahan atau penurunan kualitas telur sangat kecil terjadi pada telur yang didapat dari induk yang dipelihara dalam kandang yang dilengkapi berbagai perlengkapan pemeliharaan daripada induk yang dipelihara dalam kandang konvensional.

Pada penelitian ini, para pedagang telur di pasar Pinasungkulan Manado mendapatkan pasokan telur dari beberapa sumber atau beberapa produsen/peternak seperti dari daerah Tomohon, Pineleng, Sea, dan Malalayang, dan umumnya mereka hanya tahu telur-telur yang mereka beli dihasilkan oleh ayam-ayam ras petelur, tetapi para pedagang tidak mengetahui jenis/strain dan umur ayam ataupun kondisi lingkungan ayam penghasil telur.

\section{KESIMPULAN}

Kondisi kerabang ayam ras petelur cokelat ukuran telur kecil lebih baik dari kondisi kerabang telur ukuran sedang dan telur ukuran besar, dilihat dari kebersihan, tekstur dan warna kerabang, juga didapati bahwa pedagang telur di pasar Pinasungkulan Manado membuat kategori ukuran atau berat telur belum secara baik dan terstandar.

\section{DAFTAR PUSTAKA}

Afifah, N. 2013. Uji Salmonella shigella pada telur ayam yang disimpan pada suhu dan waktu yang berbeda. Edu Research 2(1): 35-46

Argo, L. B., T. Tristiarti dan I. Mangisah. 2013. Kualitas fisik telur ayam Arab Petelur fase I dengan berbagai level Azolla microphylla. Animal agriculture Journal 2(1): 445-457.
Badan Standard Nasional Indonesia (BSN). 2008. Standard Nasional Indonesia Telur Ayam Konsumsi. BSN. Jakarta

Batkowska, J., A. Brodacki dan S. Knaga. 2014. Quality of laying hen eggs during storage depending on egg weight and type of cage system (conventional vs. furnished cages). Annals of Animal Science 14(3): 707-719.

Chaemsanit, S., A. Akbar dan A.K. Anal. 2015. Isolation of total aerobic and pathogenic bacteria from table eggs and its contents. Food and Applied Bioscience Journal 3(1): 1-9.

Cook, F. dan G.M. Briggs. 1977. The Nutritive Value of Eggs. Egg Science and Technology, $2^{\text {nd }}$ Ed. Edited by W.J. Stadelman dan O.J. Cotterill. The AVI Publishing Company Inc. New York.

Hauser G.F., G.O. Hall dan J.H. Bruckner. 1952. Poultry management. J.B. Li[pincott Company. Chicago. Philadelphia. New York.

Heryandi, Y. 2006. Perbaikan kualitas telur telur ayam ras melalui perubahan waktu pemberian dan kandungan protein ransum. Jurnal Peternakan Indonesia 11(3): 261271.

Jazil, N., A. Hintono dan S. Mulyani. 2013. Penurunan kualitas telur ayam ras dengan intensitas warna cokelat kerabang berbeda selama penyimpanan. Jurnal Aplikasi Teknologi Pangan 2(1): 43-47.

Kekeocha, C.C. 1984. Marketing. Poultry Production Handbook. Pfizer Macmillan Education Ltd. London.

Kusnadi. 2007. Sifat Listrik Telur Ayam Kampung Selama Penyimpanan. Skripsi. Departemen Fisika. Fakultas Matematika dan Ilmu Pengetahuan Alam. Institut Pertanian Bogor. 
Mampioper, A., S. Rumetor dan F. Pattiselanno. 2008. Kualitas telur ayam petelur yang mendapat ransum perlakuan substitusi jagung dengan tepung singkong. TERNAK TROPIKA Journal of Tropical Animal Production 9(2): 42-51.

Messens, W., K. Grijspeerdt dan L. Herman. 2005. Eggshell penetration by Salmonella: a review. World's Poultry Science Journal 61(1): 7186.

Mine, Y. dan J. Kovacs-Nolan. 2004. Biologically active hen egg components in human health and disease. The Journal of Poultry Science 41(1): 1-29.

Ray, B. dan A. Bhunia. 2013. Fundamental Food Microbiology. $5^{\text {th }}$ ed. CRC Press. NY.

Roberts J.R. dan M. Ball. 1998. Eggshell Quality Problems: Causes and Solutions. UNE. The University of New England. Armidale, NSW. Australia.

Samiullah, S., A.S. Omar, J. Roberts dan K. Chousalkar. 2017. Effect of production system and flock age on eggshell and egg internal quality measurements. Poultry Science 96(1): 246-258.

Setiawati, T., R. Afnan dan N. Ulupi. 2016. Performa produksi dan kualitas telur ayam petelur pada sistim litter dan cage dengan suhu kandang berbeda. Jurnal Ilmu Produksi dan Teknologi Hasil Peternakan 4(1): 197-203

Steward, G.F. dan J.C. Abbott. 1972. Marketing Eggs and Poultry. Third Printing. Food and Agricultural Organization (FAO) the United Nation, Rome.

Solomon, S.E. 1991. Egg and Eggshell quality. Wolfe Publishing. London, UK.

Sudaryani, T. 2000. Kualitas Telur. Penebar Swadaya. Jakarta.
Sumarni dan N. Djuarnani. 1995. Penanganan Pasca Panen Unggas. Diktat Dep. Pertanian, Balai Pertanian Ternak. Ciawi. Bogor.

Tangkere, E.S., B. Bhandari dan J.G. Dingle. 2000. Effect of hot weather on the egg production and egg quality of caged and barn laying hens. Proceeding. Queensland Poultry Science Symposium. The World Poultry Sci. Association-Qld. Proceedings Volume 9. ISBN September 14, 2000. Pg. 1.7-9.7. The Univ. of Queensland, Qld. Australia

Wahyuningsih, E. 2019. Identifikasi bakteri Salmonella $s p$ pada telur ayam ras yang dijual di Pasar Wage Purwokerto sebagai pengembangan bahan ajar mikrobiologi. Jurnal Pendidikan Biologi 4(2): 79-83

Wedana, I. P., I.K. Wiyana dan M. Wirapartha. 2017. Pengaruh lama penyimpanan terhadap kualitas fisik telur ayam ras yang diperlihara secara intensif. Jurnal Peternakan Tropika 5(1): 1-10.

Winarno, F.G. dan S. Kaswara. 2002. Telur: Komposisi, Penanganan dan Pengolahannya. M-Brio Press. Bogor.

Wiradimadja, R., H. Burhanuddin dan D. Saefulhadjar. 2010. Peningkatan kadar Vitamin A pada telur ayam melalui penggunaan daun katuk (Sauropus androgynus L. Merr) dalam ransum. Jurnal Ilmu Ternak 10(2)

Yang, H. M., Z.Y. Wang dan J. Lu. 2009. Study on the relationship between eggshell colors and egg quality as well as shell ultrastructure in Yangzhou chicken. African Journal of Biotechnology 8(12): 2898-2902. 